Didaktik : J urnal Pendidikan Guru Sekolah Dasar, ISSN : 2477-5673

Sekolah Tinggi Keguruan dan IImu Pendidikan Subang

Volume I Nomor 2, J uli 2016

\title{
PENERAPAN MODEL PROBLEM BASED LEARNING UNTUK MENINGKATKAN KERJA SAMA DAN HASIL BELAJAR SISWA KELAS IV SDN BHAKTI WINAYA BANDUNG PADA SUBTEMA KEBERSAMAAN DALAM KEBERAGAMAN
}

\author{
Abdul Mumin Saud, S.Sos., M.Pd ${ }^{1}$ \\ Letty Oktiana, S.Pd ${ }^{2}$ \\ Dosen PGSD FKIP Unpas ${ }^{1}$ \\ Guru SDN Sukamulya II ${ }^{2}$ \\ abdul.muminsaud@yahoo.com ${ }^{1}$ \\ lettyoktiana@yahoo.co.id ${ }^{2}$
}

\begin{abstract}
The study, titled "Model Problem Based Learning to Enhance Cooperation and Learning Outcomes Student Class IV SDN Bhakti Winaya Bandung on Subtheme Unity in Diversity", against the background because of their problems in the field of the learning outcomes of students who mostly have reached completeness and lack of implementation of activities the cooperation of students during the learning process. This study uses classroom action research model, which consists of the third cycle. Each cycle consists of several actions, planning, implementation, analysis and reflection. The results of the first cycle studies show the learning outcomes of students achieving mastery percentage of $60.7 \%$ with an average value of students 2.5, for the same work values of students in this cycle are categorized in category (quite good) with the average value of students 2,4 . While the second cycle which is an improvement from the first cycle of learning outcomes increased by $85.7 \%$ with an average value of 2.8 students, and for the value of cooperation on sisklus II is categorized into categories (good) with the average value of students 3. and the third cycle which is a refinement of the second cycle increased learning outcomes by $100 \%$ with an average value of 3.7 , and for the same work values of students in the third cycle is categorized into categories (good) with the average value of 3 students, 4 . Based on the results of this study concluded that the model of problem based learning can improve cooperation and student learning outcomes in grade IV SDN Winaya Bhakti Bandung on subtema unity in diversity. Thus, problem based learning models can be used as an alternative learning models to be implemented on thematic learning.
\end{abstract}

Keywords: Student Learning, Student Collaboration, Problem Based Learning Models, Subthem of Togetherness In Various

\section{ABSTRAK}

Penelitian yang berjudul "Model Problem Based Learning untuk Meningkatkan Kerja Sama dan Hasil Belajar Siswa Kelas IV SDN Bhakti Winaya Bandung pada Subtema Kebersamaan dalam Keberagaman", dilatar belakangi 


\section{Didaktik : J urnal Pendidikan Guru Sekolah Dasar, ISSN : 2477-5673 Sekolah Tinggi Keguruan dan IImu Pendidikan Subang Volume I Nomor 2, J uli 2016}

karena adanya permasalahan di lapangan mengenai hasil belajar siswa yang sebagian besar belum mencapai ketuntasan serta kurangnya penerapan aktivitas kerja sama siswa selama proses pembelajaran. Penelitian ini menggunakan model penelitian tindakan kelas, yang terdiri dari III siklus. Setiap siklus terdiri dari beberapa tindakan, perencanaan, pelaksanaan, analisis dan refleksi. Hasil dari penelitian siklus I menunjukan hasil belajar siswa mencapai presentase ketuntasan sebesar $60,7 \%$ dengan rata-rata nilai siswa 2,5 , untuk nilai kerja sama siswa pada siklus ini dikategorikan pada katagori (cukup baik) dengan nilai ratarata siswa 2,4. Sedangkan siklus II yang merupakan perbaikan dari siklus I mengalami peningkatan hasil belajar sebesar $85,7 \%$ dengan nilai rata-rata siswa 2,8 , dan untuk nilai kerja sama pada sisklus II ini dikategorikan ke dalam kategori (baik) dengan nilai rata-rata siswa 3. Dan pada siklus III yang merupakan penyempurnaan dari siklus II mengalami peningkatan hasil belajar sebesar $100 \%$ dengan nilai rata-rata 3.7, dan untuk nilai kerja sama siswa pada siklus III ini dikategorikan ke dalam kategori (baik) dengan nilai rata-rata siswa 3,4. Berdasarkan hasil penelitian dapat disimpulkan bahwa model problem based learning dapat meningkatkan kerja sama dan hasil belajar siswa kelas IV SDN Bhakti Winaya Bandung pada subtema kebersamaan dalam keberagaman. Dengan demikian, model problem based learning dapat dijadikan sebagai salah satu alternatif model pembelajaran untuk diterapkan pada pembelajaran tematik.

Kata Kunci : Hasil Belajar Siswa, Kerja Sama Siswa, Model Problem Based Learning, Subtema Kebersamaan dalam Keberagaman

\section{PENDAHULUAN}

Pada hakikatnya pembelajaran merupakan proses sebab akibat. Guru sebagai pengajar merupakan penyebab utama terjadinya proses pembelajaran siswa. Oleh sebab itu, guru sebagai figure sentral, harus mampu menetapkan strategi pembelajaran yang tepat sehingga dapat mendorong terjadinya perbuatan belajar siswa yang aktif, produktif dan efisien. Menurut Bloom, dkk. Dalam buku Pengembangan Kurikulum dan Pembelajaran karya Asep Herry Hernawan (Asep Herry Hernawan, 2010) menjelaskan bahwa tujuan pembelajaran dapat dipilah menjadi tujuan yang bersifat kognitif (pengetahuan), afektif (sikap), psikomotorik (keterampilan). Derajat pencapaian tujuan pembelajaran ini merupakan indikator kualitas pencapaian tujuan dan hasil perbuatan belajar siswa.
Saat ini adalah saat transisi dalam bidang pendidikan. Masa beralihnya dari kurikulum KTSP 2006 ke kurikulum 2013. Di dalam kurikulum KTSP dan kurikulum sebelumnya secara garis besar lebih mengedepankan pada aspek kognitif lalu psikomotorik kemudian afektif. Hal tersebut disinyalir merupakan penyebab buruknya kualitas pendidikan di Indonesia. Maka dari itu para ahli pendidikan bekerja sama dengan pemerintah mengubah kurikulum tersebut dengan kurikulum 2013.

Kurikulum 2013 adalah kurikulum terbaru yang mulai dilaksanakan pada tahun ajaran 2013-2014 pada sekolah yang ditunjuk pemerintah, maupun sekolah yang siap melaksanakannya. Meskipun masih prematur, namun ada beberapa hal yang dirasakan oleh banyak kalangan terutama yang langsung berhadapan dengan kurikulum itu sendiri. 


\section{Didaktik : J urnal Pendidikan Guru Sekolah Dasar, ISSN : 2477-5673 \\ Sekolah Tinggi Keguruan dan IImu Pendidikan Subang Volume I Nomor 2, J uli 2016}

Terdapat beberapa hal penting dari perubahan atau penyempurnaan kurikulum tersebut, yaitu keunggulan dan kekurangan yang ada di dalamnya.

Pada kenyataannya, situasi pembelajaran yang berlangsung di sekolah kurang memenuhi syarat yang diharapkan. Khususnya di lokasi yang akan penulis teliti. Pada saat proses pembelajaran berlangsung terlihat situasi pembelajaran kurang kondusif, masih banyak siswa yang melakukan kegiatan di luar pembelajaran, seperti mengobrol pada saat pembelajaran berlangsung, tidak memperhatikan, dan pada saat pembelajaran yang dilakukan secara berkelompokpun hanya orang-orang tertentu saja yang mengerjakan tugas kelompok yang diberikan oleh guru sedangkan anggota kelompok lainnya tidak bertanggung jawab menyelesaikan tugas yang diberikan. Jadi pada saat pembelajaran secara berkelompok tidak semua anggota kelompok aktif bekerja sama mengerjakan tugas yang diberikan oleh guru. Sedangkan hasil pembelajaran bisa ditentukan dari keaktifan siswa dalam mengikuti pembelajaran yang dilakukan selama proses belajar, sementara kondisi di lapangan menunjukkan hasil belajar yang kurang memuaskan. Terbukti pada saat penulis melakukan observasi awal untuk memperoleh data mengenai hasil belajar siswa terutama pada subtema kebersamaan dalam keberagaman, setelah mengadakan tes tertulis hanya 5 orang siswa dari jumlah siswa 28 orang yang sudah memenuhi KKM yang telah ditetapkan yaitu 2,66 atau hanya sebanyak $17,8 \%$ siswa yang sudah memenuhi KKM yang telah ditentukan.
Berdasarkan permasalahan tersebut, maka diperlukan adanya suatu tindakan yang dilakukan untuk menjawab semua permasalahan yang timbul pada pembelajaran tematik di kelas IV SDN Bhakti Winaya yaitu dengan melaksanakan Penelitian Tindakan Kelas (PTK). Salah satunya adalah dengan menerapkan pendekatan dan model pembelajaran yang tepat dan sesuai dengan kondisi siswa dan materi ajar.

Salah satu alternatif dalam menyelesaikan permasalahan pembelajaran tematik adalah dengan menerapkan model Problem Based Learning (PBL). Arends (Trianto, 2010) menjelaskan bahwa:

Problem based learning (PBL) adalah suatu model pembelajaran di mana siswa mengerjakan permasalahan yang autentik dengan maksud menyusun pengetahuan mereka sendiri, mengembangkan inkuiri dan keterempilan berpikir tingkat lebih tinggi, mengembangkan kemandirian, dan percaya diri.

PBL atau pembelajaran berbasis masalah sebagai suatu pendekatan pembelajaran yang menggunakan masalah dunia nyata sebagai suatu konteks bagi siswa untuk belajar tentang cara berpikir kritis dan keterampilan pemecahan masalah, serta untuk memperoleh pengetahuan dan konsep yang esensial dari materi pelajaran.

Berdasarkan uraian di atas, peneliti menarik kesimpulan bahwa model Problem Based Learning sebaiknya digunakan dalam pembelajaran karena dengan menggunakan model Problem Based Learning akan terjadi pembelajaran yang bemakna. Siswa yang belajar memecahkan masalah akan membuat mereka menerapkan pengetahuan yang dimilikinya atau berusaha mengetahui pengetahuan 


\section{Didaktik : J urnal Pendidikan Guru Sekolah Dasar, ISSN : 2477-5673 \\ Sekolah Tinggi Keguruan dan IImu Pendidikan Subang \\ Volume I Nomor 2, J uli 2016}

yang diperlukannya. Belajar dapat semakin bermaka dan diperlukan ketika siswa berhadapan dengan situasi di mana konsep diterapkan. Selain itu melalui Problem Based Learning ini siswa dapat mengintegrasikan pengetahuan dan keterampilan secara berkesinambungan dan mengaplikasikannya dalam konteks yang relevan. Artinya apa yang mereka lakukan sesuai dengan aplikasi suatu konsep atau teori yang mereka temukan selama pembelajaran berlangsung. Problem Based Learning juga dapat meningktakan kemampuan berpikir kritis, menumbuhkan inisiatif siswa dalam bekerja sama, memotivasi internal siswa untuk belajar dan dapat mengembangkan hubungan interpersonal dalam bekerja sama secara kelompok.

Berdasarkan paparan latar belakang diatas, peneliti mengangkat judul penelitian tindakan kelas yang berjudul penerapan model problem based learning untuk meningkatkan kerja sama dan hasil belajar siswa kelas IV SDN Bhakti Winaya Bandung pada subtema kebersamaan dalam keberagaman.

\section{DASAR PEMIKIRAN}

\section{Pembelajaran Problem based Learning}

Model pembelajaran adalah kerangka konseptual yang melukiskan prosedur sistematis dalam mengorganisasikan pengalaman belajar yang digunakan sebagai pedoman untuk mencapai kompetensi tertentu. Pada tiap prosedur pembelajaran dapat dipilih berbagai macam metode pembelajaran yang relevan. Menurut Komaruddin (Sagala,
Syaiful, 2006) model diartikan sebagai kerangka konseptual yang digunakan sebagai pedoman dalam melakukan kegiatan.

Problem Based Learning (PBL) adalah kurikulum dan proses pembelajaran. Dalam kurikulumnya, dirancang masalah-masalah yang menuntut peserta didik mendapat pengetahuan penting, yang membuat mereka mahir dalam memecahkan masalah, dan memiliki model belajar sendiri serta memiliki kecakapan berpartisipasi dalam tim. Proses pembelajarannya menggunakan pendekatan yang sistemik untuk memecahkan masalah atau menghadapi tantangan yang nanti diperlukan dalam kehidupan seharihari. Ibrahim dan Nur (Rusman, 2011) mengemukakan bahwa Pembelajaran Berbasis Masalah merupakan salah satu pendekatan pembelajaran yang digunakan untuk merangsang berpikir tinggi siswa dalam situasi yang berorientasi pada masalah dunia nyata, termasuk di dalamnya belajar bagaimana belajar

Dari pemaparan di atas dapat disimpulkan bahwa model pembelajaran berbasis masalah dilakukan dengan adanya pemberian rangsangan berupa masalahmasalah yang kemudian dilakukan pemecahan masalah oleh peserta didik yang diharapkan dapat menambah keterampilan peserta didik dalam pencapaian materi pembelajaran.

\section{Kerja Sama}

Dalam kehidupan sehari-hari kerja sama sering terlihat di dalam kelas. Untuk membentuk individu peserta didik menjadi manusia yang demokratis, guru harus menekankan pelaksanaan prinsip kerja sama atau kerja kelompok. 


\section{Didaktik : J urnal Pendidikan Guru Sekolah Dasar, ISSN : 2477-5673 \\ Sekolah Tinggi Keguruan dan IImu Pendidikan Subang \\ Volume I Nomor 2, J uli 2016}

Menurut Burton (Ahmad Rohani, 2010) menjelaskan bahwa Burton sangat memperhatikan apa yang dinamakan group process atau proses kelompok, yaitu cara individu mengadakan relasi dan kerja sama dengan individu lain untuk mencapai tujuan bersama.

Kerja sama dalam kelompok yang demokratis itu yakni setiap individu yang berperan serta secara aktif dan ikut bekerja sama. Proses kelompok memiliki 2 ciri utama, peran serta individu dalam segala kegiatan dan kerja sama antar individu dalam kelompok. Tetapi, di dalamnya mungkin juga akan timbul persaingan. Persaingan disini akan timbul secara sehat dan baik, jika sebelumnya individu mendapat arahan.

Maka pada setiap pengajaran, guru hendaknya berupaya menciptakan suasana sosial yang membangkitkan kerja sama di antara peseta didik dalam menerima pelajaran sehingga pengajaran terlaksana lebih efektif dan efisien. Kelompok-kelompok kecil maupun kelompok-kelompok kelas akan sangat menguntungkan perkembangan individu dan sosial dari peserta didik, sekaligus memiliki nilai yang mendorong mereka untuk berprestasi belajar.

Dalam buku Pendidikan Karakter karya Heri Gunawan (Heri Gunawan 2012) menjelaskan bahwa, ada beberapa cara yang dapat menjadikan kerja sama dapat berjalan dengan baik dan mencapai tujuan yang telah disepakati. Hal itu dapat dimulai dengan saling terbuka, saling mengerti dan saling menghargai. Menurut (Syamsu Yusuf, 2007) mengemukakan perkembangan sosial merupakan pencapaian kematangan dalam hubungan sosial. Dapat juga diartikan sebagai proses belajar untuk menyesuaikan diri terhadap normanorma kelompok. Moral, dan tradisi; meleburkan diri menjadi suatu kesatuan dan saling berkomunikasi dan bekerjasama.

Dari pemaparan diatas dapat disimpulkan bahwa dalam bekerja sama satu tim memang membutuhkan kekompakan dan kerja sama yang solid. Tapi meski demikian, siswa juga dituntut untuk mandiri di dalam kelompok. Artinya, walau bekerja dalam tim, siswa tidak boleh hanya mengandalkan bantuan dan pertolongan rekan satu timnya. Siswa tetap harus memberikan kontribusi pribadi bagi kepentingan kelompok. Sikap kerjasama dalam kelompok merupakan perpaduan dari sikap individu yang terbentuk berdasarkan komitmen bersama yang diwujudkan berupa satu sikap dan perilaku kelompok sesuai dengan karakteristik dari pada sikap dan perilaku individu. Dan dalam kerja sama kelompok harus ada beberapa kesepakatan seperti, ada kejelasan visi dan misi kelompok yang dilahirkan secara bersama, ada partisipasi individu dalam kelompok, ada pengaruh dalam pembuatan keputusan dan harus ada interaksi yang baik antar anggota kelompok untuk berbagi informasi.

\section{Hasil Belajar}

Hasil belajar merupakan alat ukur dari kemampuan seseorang setelah mengalami suatu proses belajar. Hasil belajar dapat dikatakan sebagai produk akhir yang dihasilkan setelah mengalami proses belajar yang dapat dinyatakan dalam bentuk nilai yang diperoleh, biasanya dinyatakan dalam bentuk angka, huruf, atau kata-kata lainnya. Hasil belajar dalam pengertian banyak berhubungan 


\section{Didaktik : J urnal Pendidikan Guru Sekolah Dasar, ISSN : 2477-5673 Sekolah Tinggi Keguruan dan Ilmu Pendidikan Subang Volume I Nomor 2, J uli 2016}

dengan tujuan pembelajaran. Menurut (Suprijono, 2011) mengatakan bahwa hasil belajar adalah pola-pola perbuatan, nilainilai, pengertian-pengertian, sikapsikap, apresiasi dan keterampilan.

Pada dasarnya hasil belajar
siswa adalah kemampuankemampuan yang di miliki siswa setelah menerima pengalaman belajarnya dan cara mempelajari dengan baik atau dengan sungguhsungguh mengenai suatu konsep yang ada kemudian fakta-fakta yang terdapat di dalam konsep tersebut dibuktikan sehinggga akan terlihat hasil dari sebuah pembelajaran yang telah dilakukan. Hasil belajar dapat di lihat melalui kegiatan evaluasi yang bertujuan untuk mengukur sejauh mana siswa mencapai tujuan pembelajaran.

\section{METODE PENELITIAN}

Desain penelitian ini menggunakan model penelitian tindakan kelas yang terdiri dari 3 siklus. Setiap siklusnya meliputi tahapan perencanaan, pelaksanaan tindakan, observasi dan refleksi.

\section{HASIL PENELITIAN}

Berdasarkan kegiatan pelaksanaan siklus I perolehan hasil penilaian kerja sama siswa pada siklus I dengan pencapaian nilai siswa yang sudah memenuhi kriteria yang diharapkan yaitu berjumlah 11 siswa atau mencapai $39,2 \%$. Sisanya 17 siswa atau $60,7 \%$ belum memperlihatkan aktivitas kerja sama yang baik pada saat pembelajaran yang berlangsung secara berkelompok oleh sebab itu nilai kerja sama mereka masih kurang. data perolehan kerja sama pada siklus I ini secara rinci bisa digambarkan pada gambar 1 . Adapun grafik kerja sama siswa yang bisa digambarkan adalah sebagai berikut.

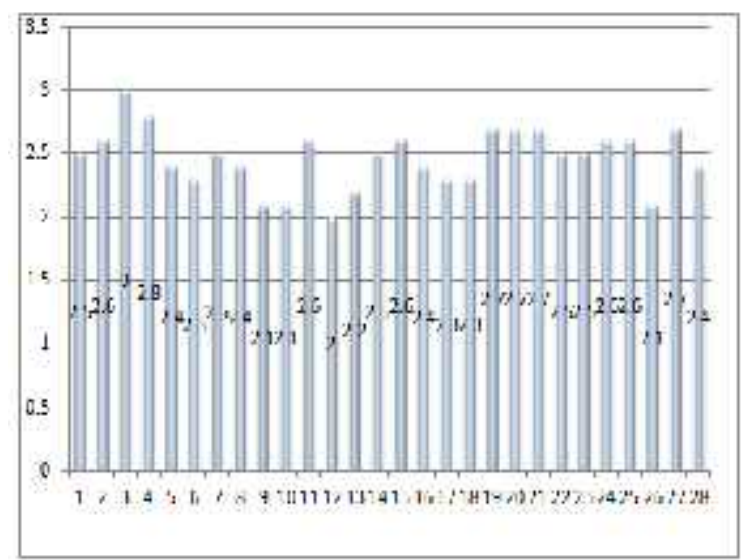

Gambar 1. Penilaian Kerja Sama Siswa Pada Siklus I

Rekapitulasi hasil belajar siswa pada siklus I diperoleh data sebagai berikut.

1. Siswa yang telah tuntas mencapai KKM sebanyak 17 orang dari jumlah siswa 28 orang atau sebanyak $60,7 \%$ katagori (cukup baik) sudah mencapai KKM.

2. Siswa yang belum tuntas mencapai KKM sebanyak 11 orang dari jumlah siswa 28 orang atau sebanyak $39,2 \%$ belum mencapai KKM. Dapat tergambar pada gambar 2 berikut ini.

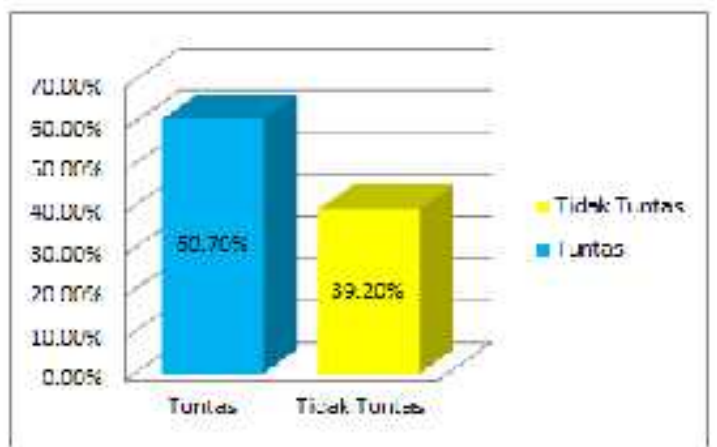

\section{Gambar 2. Hasil Belajar Siswa Siklus 1}

Berdasarkan dari perolehan nilai pada data awal dan siklus I adanya peningkatan perolehan nilai, secara rinci yaitu data awal 5 orang siswa 


\section{Didaktik : J urnal Pendidikan Guru Sekolah Dasar, ISSN : 2477-5673 \\ Sekolah Tinggi Keguruan dan Ilmu Pendidikan Subang \\ Volume I Nomor 2, J uli 2016}

atau $(17,8 \%)$ yang tuntas sedangkan pada siklus I meningkat menjadi 17 orang atau $(60,7 \%)$. Sehingga ada peningkatan jumlah siswa yang lulus sebanyak 12 orang siswa. Berdasarkan tes hasil belajar pada siklus I masih ada 11 siswa yang dinyatakan belum tuntas Berikut grafik peningkatan hasil belajar siswa.

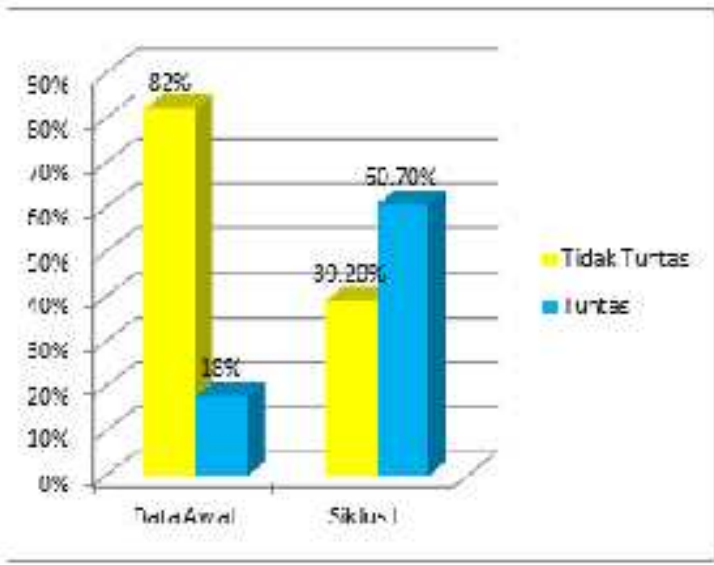

Gambar 3. Peningkatan Hasil Belajar Siswa

Dari grafik di atas kita dapat melihat gambaran peningkatan hasil belajar siswa dilihat dari data awal yang menunjukkan hanya ada $18 \%$ siswa yang tuntas memenuhi KKM sedangkan $82 \%$ lainnya belum tuntas, setelah peneliti melakukan pembelajaran siklus I jumlah siswa yang tuntas meningkat cukup derastis menjadi $60,7 \%$ sedangkan sisanya $39,2 \%$ yang belum tuntas atau belum memenuhi KKM yang sudah ditetapkan yaitu 2,66.

Hal ini menunjukkan bahwa adanya peningkatan keberhasilan dalam kualitas belajar yang dilakukan oleh guru sehingga hasil belajar siswa menjadi lebih meningkat, meskipun masih ada siswa yang belum tuntas atau belum memenuhi KKM yang telah ditetapkan. Oleh karena itu harus dilakukan tindakan siklus II agar hasil belajar siswa bisa lebih meningkat dari sebelumnnya, sehingga hasil belajar dari semua siswa dapat memnuhi KKM yang telah ditetapkan.

Pada siklus II, diketahui perolehan hasil kerja sama siswa pada siklus II dengan pencapaian nilai siswa yang sudah memenuhi kriteria yang diharapkan yaitu berjumlah 27 siswa atau mencapai $96,4 \%$. Sisanya 1 orang siswa atau $3,5 \%$ belum memperlihatkan aktivitas kerja sama yang baik pada saat pembelajaran yang berlangsung secara berkelompk oleh sebab itu nilai kerja sama yang didapatkan masih kurang. data perolehan kerja sama pada siklus II ini secara rinci ada pada Gambar 4. Adapun grafik kerja sama siswa yang bisa digambarkan adalah sebagai berikut.

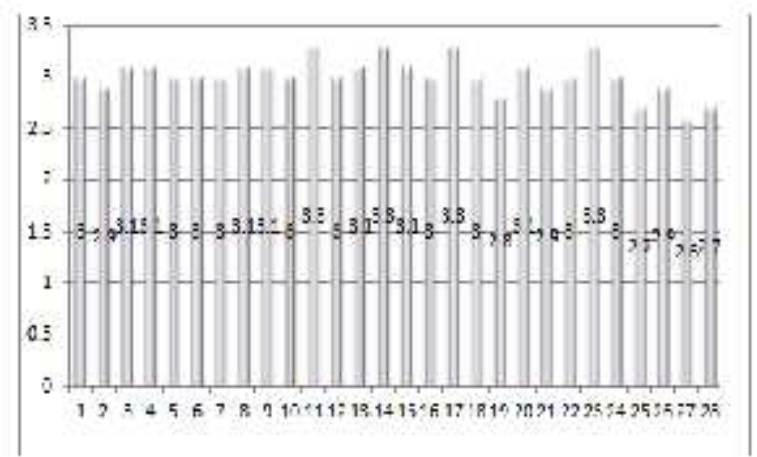

\section{Gambar 4. Penilaian Kerja Sama Siswa Pada Siklus I}

Rekapitulasi hasil belajar siswa pada siklus II diperoleh data sebagai berikut.

1. Siswa yang telah tuntas mencapai KKM sebanyak 24 orang dari jumlah siswa 28 orang atau sebanyak 85,7\% katagori (Baik) sudah mencapai KKM.

2. Siswa yang belum tuntas mencapai KKM sebanyak 4 orang dari jumlah siswa 28 orang atau sebanyak $14,3 \%$ belum mencapai KKM.

Data hasil belajar siswa yang diperoleh pada siklus II ini menunjukkan peningkatan yang cukup baik, terlihat dari nilai yang 


\section{Didaktik : J urnal Pendidikan Guru Sekolah Dasar, ISSN : 2477-5673 Sekolah Tinggi Keguruan dan IImu Pendidikan Subang Volume I Nomor 2, J uli 2016}

diperoleh siswa yang sudah memenuhi KKM yaitu sebanyak 24 siswa, sedangkan pada siklus I sebelumnya siswa yang memenuhi KKM hanya 17 orang siswa. Adapun jumlah siswa yang belum mencapai KKM pada siklus II ini berjumlah 3 siswa, sedangkan pada siklus sebelumnya ada 11 siswa yang belum mencapai KKM yang sudah ditetapkan, ini menunjukkan bahwa pada siklus II ini terjadi peningkatan hasil kualitas Hasil pembelajaran yang cukup memuaskan. Data hasil belajar siswa pada siklus II ini dapat tergambar secara rinci setelah di persentasekan antara siswa yang sudah tuntas memenuhi KKM dan persentase hasil belajar siswa yang belum tuntas atau belum memenuhi KKM yang diharapkan.

Berdasarkan dari perolehan nilai pada siklus II ini terlihat ada peningkatan perolehan nilai, secara rinci yaitu siswa yang sudah tuntas memenuhi KKM adalah 24 siswa atau $(85,7 \%)$ dan yang belum tuntas yaitu 4 siswa atau (14,3\%) sedangkan pada siklus sebelumnya yaitu siklus I siswa yang belum tuntas berjumlah 11 siswa atau $(39,2 \%)$ ini menunjukkan bahwa pada siklus II ini terjadi penurunan siswa yang belum memenuhi KKM yang telah ditetapkan.

Hal ini menunjukkan bahwa adanya peningkatan keberhasilan dalam kualitas belajar yang dilakukan oleh guru sehingga hasil belajar siswa menjadi lebih meningkat, meskipun masih ada siswa yang belum tuntas atau belum memenuhi KKM yang telah ditetapkan. Oleh karena itu harus dilakukan tindakan siklus II agar hasil belajar siswa bisa lebih meningkat dari sebelumnnya, sehingga hasil belajar dari semua siswa dapat memnuhi KKM yang telah ditetapkan.
Pada siklus III, diketahui perolehan hasil kerja sama siswa pada siklus III dengan pencapaian nilai siswa yang sudah memenuhi kriteria yang diharapkan yaitu berjumlah 28 siswa atau mencapai $100 \%$ dari jumlah siswa 28 orang. Dari data perolehan kerja sama yang diperoleh siswa pada siklus III ini menunjukkan hasil yang sangat memuaskan karena pada pembelajaran siklus III ini siswa sudah terlihat aktif bekerja sama terutama pada saat pembelajaran yang berlangsung secara berkelompok.

Data hasil belajar yang diperoleh siswa pada siklus III ini menunjukkan peningkatan yang cukup baik dibandingkan pada siklus I dan siklus II, terlihat dari nilai yang diperoleh siswa yang sudah memenuhi KKM yaitu sebanyak 28 siswa dari jumlah siswa 28 orang dan hasilnya sangat memuaskan, ini menunjukkan bahwa hasil belajar semua siswa telah memenuhi KKM yang telah ditetapkan. Selain itu jumlah nilai rata-rata hasil belajar siswa sudah sangat memuaskan yaitu 3,7. Dari tabel 4.17 data rekapitulasi hasil belajar siswa pada siklus III diperoleh data sebagai berikut.

Siswa yang telah tuntas mencapai KKM sebanyak 28 orang dari jumlah siswa 28 orang atau sebanyak 100\% katagori (sangat baik) sudah mencapai KKM. Oleh karena itu karena semua siswa sudah mencapai KKM maka tindakan akan dihentikan pada siklus III ini.

Data hasil belajar siswa yang diperoleh pada siklus III ini menunjukkan peningkatan yang cukup baik, terlihat dari nilai yang diperoleh siswa yang sudah memenuhi KKM yaitu sebanyak 28 siswa, dari jumlah siswa 28 orang 


\section{Didaktik : J urnal Pendidikan Guru Sekolah Dasar, ISSN : 2477-5673 \\ Sekolah Tinggi Keguruan dan IImu Pendidikan Subang Volume I Nomor 2, J uli 2016}

sedangkan pada siklus I sebelumnya siswa yang memenuhi KKM hanya 17 orang siswa, sisanya 11 orang siswa belum memenuhi KKM, sedangkan pada siklus II meningkat menjadi 24 siswa yang memenuhi KKM dan sisanya 4 siswa belum memenuhi KKM yang ditetapkan. Adapun jumlah siswa yang sudah mencapai KKM pada siklus III berjumlah 28 siswa dari 28 orang siswa yang berarti semua siswa sudah mencapai KKM pada siklus III ini.

Dari perolehan nilai pada siklus III ini terlihat ada peningkatan perolehan nilai, secara rinci yaitu siswa yang sudah tuntas memenuhi KKM adalah 28 siswa atau (100\%) dan yang belum tuntas tidak ada sedangkan pada siklus sebelumnya yaitu siklus I siswa yang belum tuntas berjumlah 11 siswa atau (39.2\%) dan pada siklus II ada 4 siswa atau $(14,3 \%)$ ini menunjukkan bahwa pada siklus III ini terjadi penurunan siswa yang belum memenuhi KKM yang telah ditetapkan. Dan hal ini menunjukkan adanya peningkatan keberhasilan dalam kualitas belajar yang dilakukan oleh guru sehingga hasil belajar siswa menjadi lebih meningkat dan hasil belajar siswa secara rata-rata sudah sangat memuaskan dengan pencapaian hasil belajar mereka yang sudah memenuhi KKM yang telah di tetapkan yaitu 2,66.

\section{PEMBAHASAN}

Dari hasil pembelajaran dengan menerapkan model problem based learning penulis menggunakan jawaban-jawaban dari soal-soal yang diberikan untuk mengetahui apakah materi subtema Kebersamaan Dalam Keberagaman dengan menggunakan model Problem Based Learning tersebut dapat meningkatkan kerja sama dan hasil belajar siswa kelas IV SDN Bhakti Winaya Kecamatan Regol Kota Bandung. Data peningkatan kerja sama dan hasil belajar ini diperoleh pada pembelajaran siklus I yang dilaksanakan pada tanggal 19 Agustus 2014, siklus II pada tanggal 20 Agustus 2014 dan siklus III yang dilaksanakan pada tanggal 21 Agustus 2014.

nilai rata- rata kerja sama siswa pada siklus I adalah 2,4 terus meningkat pada siklus II menjadi 3 dan pada siklus III adalah 3,4. Hal ini menunjukkan bahwa model problem based learning tepat digunakan pada materi subtema Kebersamaan Dalam Keberagaman. Peningkatan rata-rata nilai siswa juga ditunjang oleh peningkatan nilai terendah dan nilai tertinggi siswa setiap siklus.

nilai tertinggi pada siklus I adalah 2,8 kemudian meningkat pada siklus II dengan nilai 3,3 kemudian meningkat lagi pada siklus III dengan nilai 3,7. Selanjutnya nilai terendah pada siklus I adalah 2 kemudian meningkat menjadi 2,6 dan pada siklus III menjadi 3,1. Hal ini membuktikan bahwa model problem based learning tepat digunakan pada materi subtema Kebersamaan Dalam Keberagaman. Adapun peningkatan nilai hasil belajar yang diperoleh siswa yang diperoleh pada siklus I, siklus II dan siklus III.

Nilai rata- rata hasil belajar siswa pada siklus I adalah 2,5 terus meningkat pada siklus II menjadi 2,8 dan pada siklus III adalah 3,7. Hal ini menunjukkan bahwa model problem based learning tepat digunakan pada materi subtema Kebersamaan Dalam Keberagaman. Peningkatan rata-rata nilai siswa juga ditunjang oleh peningkatan nilai terendah dan nilai tertinggi siswa setiap siklus 


\section{Didaktik : J urnal Pendidikan Guru Sekolah Dasar, ISSN : 2477-5673 \\ Sekolah Tinggi Keguruan dan IImu Pendidikan Subang Volume I Nomor 2, J uli 2016}

Hasil penelitian selama tiga siklus yang bertujuan untuk meningkatkan kerja sama dan hasil belajar siswa kelas IV SDN Bhakti Winaya pada subtema Kebersamaan Dalam Keberagaman terlihat pada pelaksanaan siklus I, II dan III telah menunjukkan hal-hal yang baik seperti pada proses pembelajaran subtema Kebersamaan Dalam Keberagaman dengan menggunakan model Problem Based Learning ditinjau dari segi interaksi siswa dengan guru di awal pelajaran dibuka dengan menggunakan model problem based learning sebagai titik tolak pembelajaran. Guru mengarahkan diskusi pada saat proses pembelajaran berlangsung. Guru pun mengelola kelas secara interaktif dalam memotivasi dan membimbng siswa untuk aktif berperan dalam kegiatan pembelajaran supaya kerja sama siswa terutama pada saat pembelajaran secara berkelompok dapat meningkat dan hasil belajar yang diperoleh siswa akan lebih baik.

\section{KESIMPULAN}

Berdasarkan hasil penelitian yang berjudul "Penerapan Model Problem Based Learning Untuk Meningkatkan Kerja Sama Dan Hasil Belajar Siswa Kelas IV SDN Bhakti Winaya Bandung Pada Subtema Kebersamaan Dalam Keberagaman" penulis dapat mengambil kesimpulan sebagai berikut.

1. Dari perencanaan pembelajaran Tematik dikelas IV SDN Bhakti Winaya kecamatan Regol kota Bandung diketahui bahwa dengan menggunakan model Problem Based Learning dapat meningkatkan kerja sama dan hasil belajar siswa dalam pembelajaran
Tematik SD khususnya pada tema Indahnya Kebersamaan Subtema Kebersamaan Dalam Keberagaman Pembelajaran 1, pembelajaran 2 dan pembelajaran 3.

2. Kerja sama dan hasil belajar siswa sebelum penggunaan model Problem Based Learning pada pembelajaran tematik khususnya kelas IV pada pembelajaran 1,2 dan 3 SDN Bhakti Winaya kecamatan Regol kota Bandung masih rendah, hal tersebut dapat di lihat dari hasil pretes yang dilakukan oleh peneliti. Setelah pembelajaran dilakukan dengan menggunakan model Problem Based Learning barulah kerja sama dan hasil belajar siswa meningkat pada setiap siklusnya.

3. Persentase peningkatan aktivitas kerja sama dan hasil belajar siswa pada siklus I yang berhasil mencapai batas nilai standar adalah 39,2\% dari jumlah siswa 28 orang, karena 17 siswa nilainya masih dibawah batas nilai standar. Pada siklus II meningkat menjadi $96,4 \%$ karena terdapat 1 siswa yang belum memenuhi standar. Dan pada siklus III terjadi peningkatan $100 \%$ karena nilai kerja sama semua siswa sudah memenuhi standar.

4. Persentase peningkatan hasil belajar siswa pada siklus I yang berhasil mencapai batas nilai standar adalah $32 \%$ dari jumlah siswa 28 orang, karena 19 siswa nilainya masih dibawah batas nilai standar. Pada siklus II meningkat menjadi $89,2 \%$ karena masih terdapat 3 siswa yang belum memenuhi standar. Dan pada siklus III terjadi peningkatan menjadi 96,4\% karena masih terdapat satu siswa yang belum memenuhi standar. 


\section{Didaktik : J urnal Pendidikan Guru Sekolah Dasar, ISSN : 2477-5673 \\ Sekolah Tinggi Keguruan dan IImu Pendidikan Subang Volume I Nomor 2, J uli 2016}

5. Berdasarkan hipotesis yang penulis ajukan, dapat disimpulkan bahwa jumlah nilai kerja sama keseluruhan siswa pada siklus I ialah 69,1 dengan persentase kerja sama mencapai $39,2 \%$, siklus II jumlah nilai kerja sama keseluruhan siswa ialah 84,4 dengan persentase $96,4 \%$ dan siklus III jumlah nilai keseluruhan siswa ialah 96,7 dengan persentase $100 \%$. Sedangkan hasil belajar siswa pada siklus I jumlah nilai keseluruhan siswa ialah 71,2 atau $60,7 \%$, siklus II jumlah nilai keseluruhan siswa ialah 80,8 atau $85,7 \%$ dan siklus III jumlah nilai keseluruhan siswa ialah 103,2 atau $100 \%$. Hal ini terbukti berdasarkan uji statistik yang menunjukkan $\mathrm{t}$ hitung $>\mathrm{t}$ tabel. Pada siklus I, t hitung $=4,3>$ $\mathrm{t}$ tabel $=2,05$ dan derajat kebebasan 27. Pada siklus II, $t$ hitung $=3,7>\mathrm{t}$ tabel $=2,05$ dan derajat kebebasan 27. Sedangkan pada siklus III, $\mathrm{t}$ hitung $=3,1>\mathrm{t}$ tabel = 2,07 dan derajat kebebasan 22. Hal ini menunjukkan bahwa terdapat perbedaan antara uji hasil statistik pada siklus I, siklus II, dan siklus III. Dengan demikian, model problem based learning dapat digunakan dalam pembelajaran tematik subtema kebersamaan dalam keberagaman yang terbukti dapat meningkatkan kerja sama dan hasil belajar siswa kelas IV SDN Bhakti Winaya.

\section{DAFTAR PUSTAKA}

Agus, Suprijono. 2011. Cooperative Learning Teori dan Aplikasi Paikem. Yogyakarta : Pustaka Pelajar.

Gunawan, Heri. 2012. Pendidikan Karakter. Bandung : Alfabeta.
Rohani, Ahmad. 2010. Pengelolaan Pengajaran. Jakarta : PT Rineka Cipta.

Rusman. 2011. Model-model Pembelajaran Menyenangkan Profesionalisme Guru. Jakarta : PT Raja Grafindo Persada.

Sagala, Syaiful. 2006. Konsep Belajar dan Pembelajaran. Jakarta : Alfabeta.

Sardiman, A. M. 2004. Interaksi dan Motivasi Belajar Mengajar. Jakarta : Rajawali.

Suherman, Erman. 2001. Strategi Pembelajaran Matematika Kontemporer. Bandung : JICA-UPI.

Tim FKIP Unpas. 2014. Panduan Penyusunan Skripsi, Skripsi dan Artikel Jurnal IImiah. Bandung : Pelangi Press.

Tim Kemendikbud.2014. Materi Pelatihan Kurikulum 2013. Jakarta : Kemendikbud.

Trianto, 2010. Desain Model Pembelajaran Inovatif. Bandung : Alfabeta 